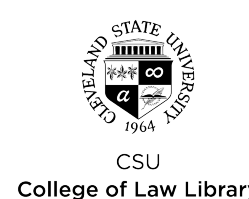

Cleveland State University

College of Law Library

\title{
EngagedScholarship@CSU
}

2000

\section{Environmental and Brownfield Liability: Relative Influence on Corporate Expansion and Relocation}

Heidi Gorovitz Robertson

Cleveland State University, h.robertson@csuohio.edu

Alan K. Reichert

Follow this and additional works at: https://engagedscholarship.csuohio.edu/fac_articles

Part of the Environmental Law Commons, and the Land Use Law Commons

How does access to this work benefit you? Let us know!

Original Citation

Heidi Gorovitz Robertson, Environmental and Brownfield Liability: Relative Influence on Corporate Expansion and Relocation, 2 Journal of Corporate Real Estate 315 (2000)

This Article is brought to you for free and open access by the Faculty Scholarship at EngagedScholarship@CSU. It has been accepted for inclusion in Law Faculty Articles and Essays by an authorized administrator of EngagedScholarship@CSU. For more information, please contact research.services@law.csuohio.edu. 


\title{
Environmental and brownfield liability: Relative influence on corporate expansion and relocation
}

\author{
Heidi Gorovitz Robertson and Alan K. Reichert \\ Received (in revised form): 5 th June, 2000 \\ Professor Heidi G. Robertson, College of Law, Cleveland State University, 1801 \\ Euclid Avenue, Cleveland Oh 44115, Ohio, USA; Tel: +1 (216) 687-9264; \\ Fax: +1 (216) 687-6881; e-mail: heidi.robertson@law.csuohio.edu
}

Heidi Gorovitz Robertson is Associate Professor of Law at the Cleveland-Marshall College of Law, and Associate Professor of Environmental Studies at the Levin College of Urban Affairs, both at Cleveland State University. Professor Robertson practised environmental law with the law firm of Pillsbury Madison \& Sutro in San Francisco, CA and Washington, DC. She serves on the Board of Directors of the Clean Air Conservancy.

Professor Alan K. Reichert received his PhD from the Ohio State University. His research interests include assessing environmental impacts on property values and a wide range of commercial banking issues.

\section{Abstract}

Many States in America have enacted laws to encourage redevelopment of contaminated urban properties. The laws attempt to do this by addressing one barrier to redevelopment, the environmental liability attached to contaminated urban properties. In general, the laus attempt to remove or reduce the significance of that barrier by reducing or eliminating the environmental liability risk attached to these properties. Our hypothesis was that these efforts cannot encourage significant redevelopment because they fail to address non-environ- mental barriers to urban redevelopment. To determine whether this legislative focus on environmental liability is misplaced, we conducted a-survey of Northeast Ohio businesses which had decided, since the enactment of Ohio's brownfields law, either to move to a new location, or to expand at an existing location. The survey asked businesses to rank the relative importance to their relocation decision of environmental and non-environmental factors. The results of the survey show that numerous non-environmental factors were of equal or greater importance to decision-makers than the environmental status of the property. Therefore, legislative efforts to encourage redevelopment of contaminated urban properties must be expanded to address non-environmental barriers to redevelopment

Keywords: brownfields, business decision-making, contaminated properties, corporate relocation, corporate expansion, environmental liability, redevelopment, site selection.

\section{INTRODUCTION}

Throughout the United States, federal, state and local governments have been working to encourage the clean-up and redevelopment of contaminated land,
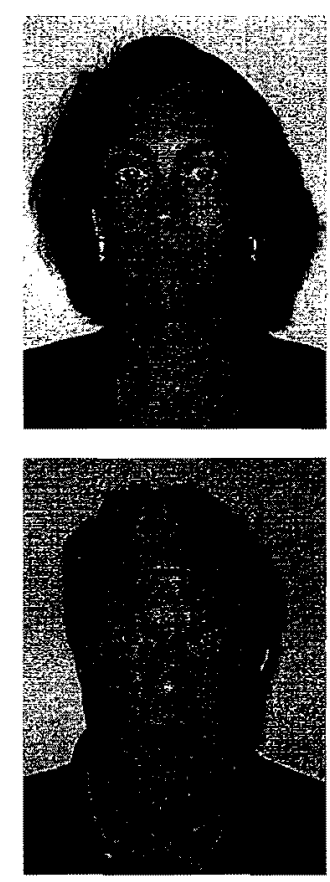

Journal of Corpotate Real Estate Vol. 2 No. 4, 2000, pp. 315-329. CHenry Stewart Publications. 1463-001X 
called 'brownfields'.' Their efforts are attempts to revitalise economies, thus stimulating job creation and the tax base, and to invigorate communities by improving aesthetics and environmental quality. Towards those ends, in 1994 the Ohio Legislature enacted Ohio's Voluntary Action Program (VAP) to encourage the redevelopment of contaminated land. ${ }^{2}$ The hope was to create a programme that would encourage businesses to clean and redevelop properties, thus turning them into productive participants in the state and local economies. To do so, the VAP sets clean-up standards, which can show landowners clearly how much work they need to do on the property. In addition, the VAP reduces government involvement in the clean-up process by assigning much of the oversight responsibility to the private sector, and provides tax incentives for participation.

To participate in the VAP, designated parties retain a private environmental professional, called a 'certified professional', to oversee and carry out the site clean-up. Upon its completion, the certified professional issues a 'no further action' letter and forwards it to the Ohio Environmental Protection Agency (EPA). The Ohio EPA then issues a 'covenant not to sue', which provides the recipient with protection against future claims by the state.

This programme was designed to encourage redevelopment of contaminated sites by reducing the threat of environmental liability. The hope was that with the liability protection offered by the VAP's covenants not to sue, businesses would choose to clean and redevelop brownfield sites. At the time of its enactment, the VAP was viewed as a potentially powerful tool for urban redevelopment and renewal. At the time of this survey, however, only 32 sites had been remediated under the VAP, many of them not sites that were 'out of circulation'.

The relatively low number of participants led us to question the central premise of the programme: that the reduction of environmental liability will lead businesses to choose to clean and redevelop brownfield sites. To be true, the environmental or brownfield status of the site must be critical to businesses' siteselection decision-making process. Therefore, to determine why the VAP was less successful than many expected, we conducted a survey (described below) to determine the relative importance of various factors, both environmental and non-environmental, to businesses' siteselection decisions.

The survey was carried out in the Greater Cleveland, Ohio area to determine the relative importance of various factors companies consider when choosing a new business location. In particular, the purpose of the survey was to determine whether companies consider brownfreld issues in their decision-making and, if so, how important potential environmental liability was to their relocation decision. To determine the relative importance of the environmental status of a potential site, the survey asked companies about other factors possibly relevant to their relocation or expansion decision.

The survey provided a list of factors potentially important to a relocation decision and asked the companies to rank the importance of each factor in the overall decision-making process on a scale from one to five, with five indicating that the factor was very important. Respondents were asked to evaluate the importance of the following issues: site location; site size and configuration; accessibility of transportation; taxes, tax abatements or other economic incentives; cost of renovation or construction; access to a 
skilled work force; cost of utilities and insurance; crime and safety; potential environmental liability; and the need for a new or existing building. In a number of cases additional interrelated sub-questions were asked, to understand better the company's position with respect to the issue. The final series of questions asked the respondent to choose and rank the three most important factors in making the actual relocation decision.

\section{LITERATURE REVIEW}

To provide background and some historical context, we include a brief review of the literature on corporate site selection. A survey by Roth (1983) of companies in 35 cities revealed that the issues of prime importance to corporate executives when making decisions regarding corporate relocations were: first, convenience of an operational location; secondly, economic advantage of a location; and thirdly, quality of life. $^{3}$ Other important factors included obsolescence of existing premises; shifts in the availability of needed support services; and changing demographic patterns. At that time companies were finding suburbs more attractive for offices, mostly because of high rents in the central business districts, less stringent building codes, and cheaper land. This study noted that quality-of-life concerns were becoming more important in corporate decision-making.

Another mid-1980s study by Goldstein indicated that the factors most important to site-selection decisions were geographical location, high worker productivity, land transportation and a low union profile. ${ }^{4}$ Of lesser importance were a stable state government, skilled labour availability, long-term financing, and energy source. All other factors were slightly less important. The list of factors did not include the environmental or brownfield status of candidate sites.

Bowlby's comprehensive Canadian study of corporate relocation decisions (1988) asked executives to evaluate 20 criteria important to their relocation decisions. ${ }^{5}$ Although the environmental legal landscape in Canada is different from that in the United States, notably absent from the list of criteria was any reference to the environmental status of the site; decision-makers therefore had no opportunity to describe the role of brownfield issues in their decisionmaking. This study noted that early approaches to understanding corporate location decisions were grounded in rational economic behaviour. It noted that corporations selected the best combination of site costs, market costs, and the financial impact of both technological factors and government intervention. It concluded that corporate location decisions are actually more complicated than they first appear. Many factors that influence location decisions are not easily or reliably measured. The study concluded, therefore, that decision theories that exclude or fail to address these factors are incomplete and unreliable. The study argued that examining the priorities companies place on a variety of location criteria can help economic development officials to understand corporate location decisions better, which in turn can lead to better resource allocation decisions.

This same Canadian study found that factors central to the relocation decision include market size, labour pool, market potential and whether or not the area is a financial centre. Factors that respondents often mentioned as relevant to the decision, but not highly rated as being very important, included cost base, accessibility, infrastructure, market proximity and internal transportation. Factors cited infrequently by respondents, 
but ranked high in importance, included raw material availability, demographics, economic stability, organisational fit and labour stability. Factors that the study found less important to location decisions included taxes, tourism, competition, quality of life, utility services and government support. ${ }^{6}$

According to Tiller (1994), corporate real estate executives, economic development officials and site-selection consultants agree that although transportation access, utilities, the availability of services, and quality of life all play a role in corporate site-selection decisions, the financial bottom line is still the most important factor. ${ }^{7}$ Furthermore, the relative importance of various factors will vary by type of business. ${ }^{8}$ For example, retailers find the size of the local market a high priority, whereas manufacturers find it more important to be near raw materials and an appropriate labour pool.

A recent study by Gooley (1998) finds that four factors of historical importance are still of primary importance in site selection despite fast-changing business climates. ${ }^{9}$ The first is physical infrastructure - including natural and man-made features. Second is proximity to suppliers and customers. Third are political and tax considerations - including government incentives and political climate. Fourth, for companies to which they apply, are international trade considerations such as duty rates and international transportation costs.

Focusing on the efforts of economic development offices to influence corporate relocation decisions, a study by Deliotte \& Touche Realty Consulting Group in the early 1990s, found that although incentives were important in encouraging a company to move to a particular location, they were important only once an area was on the company's short list of possible locations. ${ }^{10}$ In fact, the study revealed that incentives ranked fourteenth out of a total of 17 location decision-making factors. ${ }^{11}$ Promises of infrastructure improvements, property tax abatement, tax credits, subsidised training and other incentives do not play a major role for companies in the early stages of site selection. However, in the final stages, they can be pivotal. According to a study by Pollina (1997) 82 per cent of corporations surveyed said that incentives were important in comparing their top three to five locations, and 61 per cent said they were important in making the final location selection. Thus, taken alone, incentives are a poor reason to relocate; but they can be a critical element in a final site-selection decision. ${ }^{12}$

The Deloitte study found that real estate costs ranked furst in importance, followed by labour force issues, transportation, real estate availability and market access. ${ }^{13}$ The study noted that labour force issues frequently appear near the top of many rankings. In the past, companies were looking for an abundance of cheap labour; now they are interested in more highly skilled workers and in those who meet certain educational standards. Although the results of the Deloitte study ranked the cost of real estate as the primary site-selection concern, some argue that, in reality, it is a minor consideration because it is a one-time expense. For some kinds of companies, location in relation to the applicable market is the most important consideration, in conjunction with how markets can be accessed from the location in question. For some companies, especially those making local moves, 'microlocation' issues were important, such as proximity to hotels, restaurants and freeways.

A study by Sheridan (1995) supports the conclusion that companies seeking sites to construct industrial facilities place 
a higher value on existing infrastructure than they do on promises that roads, water, and sewage works will be provided in the future. ${ }^{14}$ The same study found that furms seeking to expand place increased importance on factors that lead to a contented workforce. They evaluate the entire package of a particular site educational climate, cost of living, crime, socioeconomic status and tax environment - rather than focusing primarily on government incentives.

A joint study by Ernst \& Young's Real Estate Advisory Services and the $\mathrm{Na}$ tional Real Estate Index was designed to determine the impact of corporate relocation, expansion and consolidation on the investment real estate sector. ${ }^{15}$ As part of this effort, the study asked corporate real estate executives to identify, for office, distribution, and manufacturing concerns, the factors most important in their site-selection decision-making. This survey asked respondents to rate siteselection factors in six categories: real estate-related costs; accessibility; taxes and regulatory environment; quality of life; labour quality and availability; and infrastructure.

The Ernst \& Young study found real estate-related costs to be the most important site-selection category. The most important site-selection factor, low lease rates, was within that category. The fourth most important factor, low construction costs, also falls into the real estate-related costs category. The second highest ranked individual factor, an educated workforce, was within the category of labour quality and availability. Major highways, a factor in the infrastructure category, ranked third. Site-selection factors in the taxes and regulatory environment and quality of life categories ranked fairly low.

Although the Ernst \& Young study indicated that real estate-related costs form the most important site-selection category, like the Deloitte \& Touche study, it did not attempt to determine the extent to which environmental costs or environmental concerns were elements within that category. The Ernst \& Young conclusions are not inconsistent with the idea that potential site-specific environmental liability is a critical determinant of site selection because environmental costs and concerns could be substantial in the case of brownfields. The study does not disaggregate the term 'real estate costs', however, to determine the extent to which it might include environmental costs.

Mooney (1994) investigated the role communities play in attracting corporations to their area. ${ }^{16}$ The factors the study found to be important revolve around reducing or eliminating barriers in the development process - an idea readily transferable to cities hoping to encourage redevelopment of brownfields land. In efforts to reduce barriers to development, communities use a wide variety of incentives such as zoning adjustments, land write-downs, equipment leases, tax increment financing, deferred payment mortgages, tax abatements, enterprise or foreign trade zones, utility incentives, pre-employment screening, job training funds, temporary housing for relocating executives, special employment programmes, discounts on home furnishings and reimbursement of moving costs. Although these incentives may work well in communities that can afford the upfront costs of providing them, many cities hoping to encourage redevelopment of brownfields land may not be able to afford the upfront costs.

A 1996 survey of economic development officials found that the services they planned to provide in 1997 included: enhanced information delivery systems, such as CD-ROMs and websites; increased financial incentives; and speculative industrial buildings. ${ }^{17}$ In addition, 


\section{Table 1: Summary of literature}

\begin{tabular}{|c|c|c|c|c|c|c|c|c|c|c|}
\hline & \multicolumn{9}{|c|}{ Authors } & \multirow[b]{2}{*}{$\begin{array}{c}\text { Total } \\
\text { mentions }\end{array}$} \\
\hline & Roth & Goldstein & Bowlby & Gooley & $\begin{array}{l}\text { Deloitte } \\
\text { \& Touche }\end{array}$ & Sheridan & $\begin{array}{l}\text { Ernst \& } \\
\text { Young }\end{array}$ & $\begin{array}{c}\text { Fortune } \\
\text { Magazine }\end{array}$ & $\begin{array}{l}\text { Robertson } \\
\& \text { Reichert }\end{array}$ & \\
\hline \multicolumn{11}{|l|}{ Factors } \\
\hline Parking & & & & & & & & & 1 & 1 \\
\hline Locational convenience & & & 1 & 1 & 1 & & & & 1 & 4 \\
\hline Building size & & & & & & & & & 1 & 1 \\
\hline Existing building & & & & $1:$ & & & & & 1 & 2 \\
\hline Desired location & 1 & 1 & & 1 & & & & & 1 & 4 \\
\hline Labour skills & 1 & 1 & 1 & & 1 & 1 & 1 & 1 & 1 & 8 \\
\hline Locational safety & & & & & & & & & 1 & 1 \\
\hline Building safety & & & & & & & & & 1 & 1 \\
\hline Price land/building & 1 & & 1 & & 1 & & 1 & & 1 & 5 \\
\hline Labour costs & & 1 & 1 & & 1 & & & 1 & 1 & 5 \\
\hline Operating expense & & & & & & & & & 1 & 1 \\
\hline Environmental liability & & & & & & & & & 1 & 1 \\
\hline Market size & & & 1 & & & & & & & 1 \\
\hline Financial centre & & & 1 & & & & & & & 2 \\
\hline Raw material costs & & & 1 & & & & & & 1 & 1 \\
\hline Quality of life & 1 & & & & & 1 & 1 & & & 4 \\
\hline Transportation & & 1 & 1 & 1 & 1 & 1 & 1 & 1 & 1 & 8 \\
\hline Political climate & & 1 & 1 & 1 & & & & 1 & 1 & 4 \\
\hline Tax abatement & & & & 1 & 1 & 1 & 1 & & & 5 \\
\hline Economic stability & & & 1 & & & & & & 1 & 1 \\
\hline Infrastructure & & & & & & 1 & & 1 & & 2 \\
\hline Cost of living & & & & & & 1 & & & & 1 \\
\hline Total Factors Per Author & 4 & 5 & 10 & 6 & 6 & 6 & 5 & 5 & 16 & 63 \\
\hline
\end{tabular}


development officials said they would place increased emphasis on sites and buildings and provide increased services to site seekers. ${ }^{18}$ These changes, should states and counties focus them on brownfields redevelopment, could increase the success of existing brownfields programmes.

To help summarise the literature, Table 1 indicates which broad categories of factors were considered in some of the more comprehensive studies, including the current study. The single most widely considered factor relates to total costs, followed closely by the convenience and accessibility of the location, and labour issues. Transport issues, financing and tax abatement considerations were ranked third. Quality of life, market issues, and utility issues were ranked fourth. The current study is the only one explicitly considering environmental factors.

As discussed above, missing from the corporate site selection literature is any consideration of the environmental or brownfield status of candidate sites as a factor in corporate relocation decisions. One reason the literature has neglected environmental costs as a sub-set of 'real estate costs' may be that it is a relatively new factor that will influence some industries. ${ }^{19}$ Another possible explanation for the lack of consideration of the environmental status of the site is that many of these studies were done by economic development interests. Economic development offices have an interest in luring businesses to their area and may not see discussion of possible contamination as a selling point, even in the light of strong clean-up and redevelopment incentives. Finally, there may well be studies that include brownfield issues and the environmental status of the site in other disciplinary areas, such as environmental policy or the lending behaviour of financial institutions.
One would expect that when evaluating the potential sites in terms of costs and regulatory requirements, the environmental status of the sites would be important. However, the literature of corporate site-selection and relocation decisionmaking has neglected to evaluate the way companies value the environmental status of candidate sites in their relocation decisions. Although past studies certainly evaluate 'real estate costs', they have not separated environmental costs from that broader category.

\section{SURVEY PROCEDURES AND SAMPLE DESCRIPTION}

The sample was obtained using the following methods. First, Cleveland area economic development personnel and real estate developers were contacted regarding information on companies new to the area, companies expanding in their own area, and companies leaving the area since 1994. In addition, the Cleveland Plain Dealer and Crain's Cleveland Business newspapers were searched for stories on north-east Ohio companies that had expanded or relocated since 1994. Approximately 80 companies were identified and contacted by telephone between March and July 1997 to request their participation in the survey; 59 agreed to participate, with 34 firms actually completing the survey. The companies responded either by telephone or by completing a detailed written questionnaire.

The companies completing the survey are quite diverse. They include a commercial bank, a home healthcare service, a commercial real estate developer, two lumber yards, a furniture showroom, a vacuum-cleaner assembler, an industrial laundry, a meat processor and food distributor, plus manufacturers and distributors of a variety 
of wholesale products. Sixty-five per cent of the respondents are service firms, while the remaining 35 per cent engage in some form of manufacturing. The number of employees for the entire sample ranged from 5-700, with an average employment base of 119 . An analysis by type of firm indicated a mean value of 162 employees for the manufacturing firms and an average employment base of 99 for the services firms. (Given the limited sample size and the large dispersion in the data, this difference proved not to be statistically significant.)

\section{EMPIRICAL RESULTS}

\section{Screening criteria}

As mentioned above, respondents were asked to rate, on a scale from one to five, the level of importance of each of the following factors in deciding where to locate their company (with a rating of five being the most important factor):

- site location and accessibility

- site size and configuration

- accessibility of transportation

- local zoning

- property taxes

- cost and availability of skilled labour

- utilities

- cost and availability of property and liability insurance

- crime and public safety

- cost of labour and land

- environmental liability.

Table 2 provides the mean ratings and ranking for 28 variables which describe these 11 categories. For convenience, the ratings were categorised into three basic groups, structure and cost, amenities and location. To isolate these three groups, the factor ratings were first grouped by indicated importance to the site selection decision. Factors with ratings above 3.8 compose the High Priority group $(\mathrm{H})$. Those with ratings from 3.2-3.7 define the Medium Priority group (M). Ratings in the range 2.4-3.0 constitute a Lower Priority group (L), while factors rated below 2.4 define a Very Low Priority group (VL). The factors in the High Priority group included key property characteristics, such as size of building (amount of space) and locational preference; safety concerns related to both the neighbourhood and the building; and expense-related issues, such as building and land prices, maintenance costs and potential environmental liability. Medium Priority issues relate to parking, employee convenience, number of floors, access to a new or existing building, tax abatements or incentives, availability of skilled labour, and costs of construction or renovation. Low Priority factors include access to airport and public transportation, nearness to other businesses, amount of surround-ing land, zoning and property taxes, utilities and insurance. Access to shipping and rail transportation was ranked in the Very Low Priority group. Figure 1 visually displays these results by ranking the factors from most to least important.

Factor analysis was used to reduce the number of variables to a common set of factors which seem to drive the decisionmaking process. Given the limited sample size $(n=34)$, it was not possible to conduct a factor analysis using all 28 variables listed in Table 2. A subset of the 15 most important variables, those with a mean rating of 3.4 and above, was included in a principal component factor analysis using oblique factor rotation. Table 3 reports the statistical results of the analysis, while Figure 2 depicts the component factor loadings for 13 of the variables. (Two variables, cost of construction or renovation and ability to construct a new building, were excluded because of high 
Table 2: Relative importance of various screening factors

\begin{tabular}{|c|c|c|c|c|}
\hline Factor & & Mean rating & Rank & Priority group \\
\hline \multirow{10}{*}{ S } & Site location and accessibility & & & \\
\hline & (a) major highways access & 3.9 & 4 & $\mathrm{H}$ \\
\hline & (b) airport access & 2.5 & 14 & $\mathrm{~L}$ \\
\hline & (c) parking & 3.5 & 6 & $M$ \\
\hline & (d) access to public transportation & 2.4 & 15 & $\mathrm{~L}$ \\
\hline & (e) access to lake shipping & 1.3 & 16 & VL \\
\hline & (f) access to rail shipping & 1.3 & 16 & VL \\
\hline & (g) convenience for employees & 3.6 & 5 & $\mathrm{M}$ \\
\hline & (h) achieving preference location & 3.9 & 4 & $\mathrm{H}$ \\
\hline & (i) nearness to other businesses & 3.0 & 10 & $L$ \\
\hline \multirow{6}{*}{ 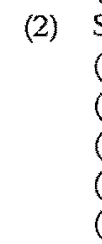 } & Site size and configuration & & & \\
\hline & (a) amount of space & 4.6 & 1 & $\mathrm{H}$ \\
\hline & (b) number of floors & 3.3 & 8 & $\mathrm{M}$ \\
\hline & (c) amount of surrounding land & 3.0 & 10 & $\mathrm{~L}$ \\
\hline & (d) availability of existing building & 3.6 & 5 & $\mathrm{M}$ \\
\hline & (e) ability to construct new building & 3.4 & 7 & $\mathrm{M}$ \\
\hline (3) & Zoning & 2.9 & 11 & $\mathbf{L}$ \\
\hline (4) & Property taxes & 2.6 & 13 & $\mathrm{~L}$ \\
\hline (5) & Tax abatement/incentives & 3.2 & 9 & $\mathrm{M}$ \\
\hline (6) & Availability of skilled labour & 3.4 & 7 & $\mathrm{M}$ \\
\hline \multirow{3}{*}{ (7) } & Utilities & & & \\
\hline & (a) price & 2.7 & 12 & $\mathrm{~L}$ \\
\hline & (b) special rate/discount & 2.5 & 14. & $\mathrm{~L}$ \\
\hline (8) & Price of property and liability insurance & 2.4 & 15 & $\mathrm{~L}$ \\
\hline \multirow[t]{3}{*}{ (9) } & Crime and public safety & & & \\
\hline & (a) locational safety & 3.9 & 4 & $\mathrm{H}$ \\
\hline & (b) building safety & 3.9 & 4 & $\mathrm{H}$ \\
\hline \multirow{5}{*}{ 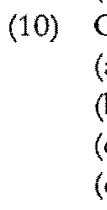 } & Cost of labour and land & & & \\
\hline & (a) price of land/building & 4.2 & 2 & $\mathrm{H}$ \\
\hline & (b) cost of construction/renovation & 3.5 & 6 & $M$ \\
\hline & (c) maintenance costs & 4.2 & 2 & $H$ \\
\hline & (d) labour costs & 3.4 & 7 & $M$ \\
\hline (11) & Environmental/brownfield liability & 4.0 & 3 & $\mathrm{H}$ \\
\hline
\end{tabular}

intercorrelations. The variable numbers referred to in Figure 2 are identified in Table 3.)

The following interpretation has been assigned to the three factors identified in the analysis: Structure and Cost (Factor 1), Amenities (Factor 2) and Location (Factor 3). The factor analysis explained over 70 per cent of the total variation in the data, with the proportion of total variance explained by each of the three factors as follows: 36.2 per cent Factor 1; 17.7 per cent Factor 2; and 16.3 per cent Factor 3. The factor analysis generally produced reasonable variable groupings, suggesting that the respondents answered the ques. tionnaire in a consistent and logical manner.

Factor 1: Structure and Cost

Building size

Existing building

Locational safety

Building safety 
Figure 1 Factor ranking

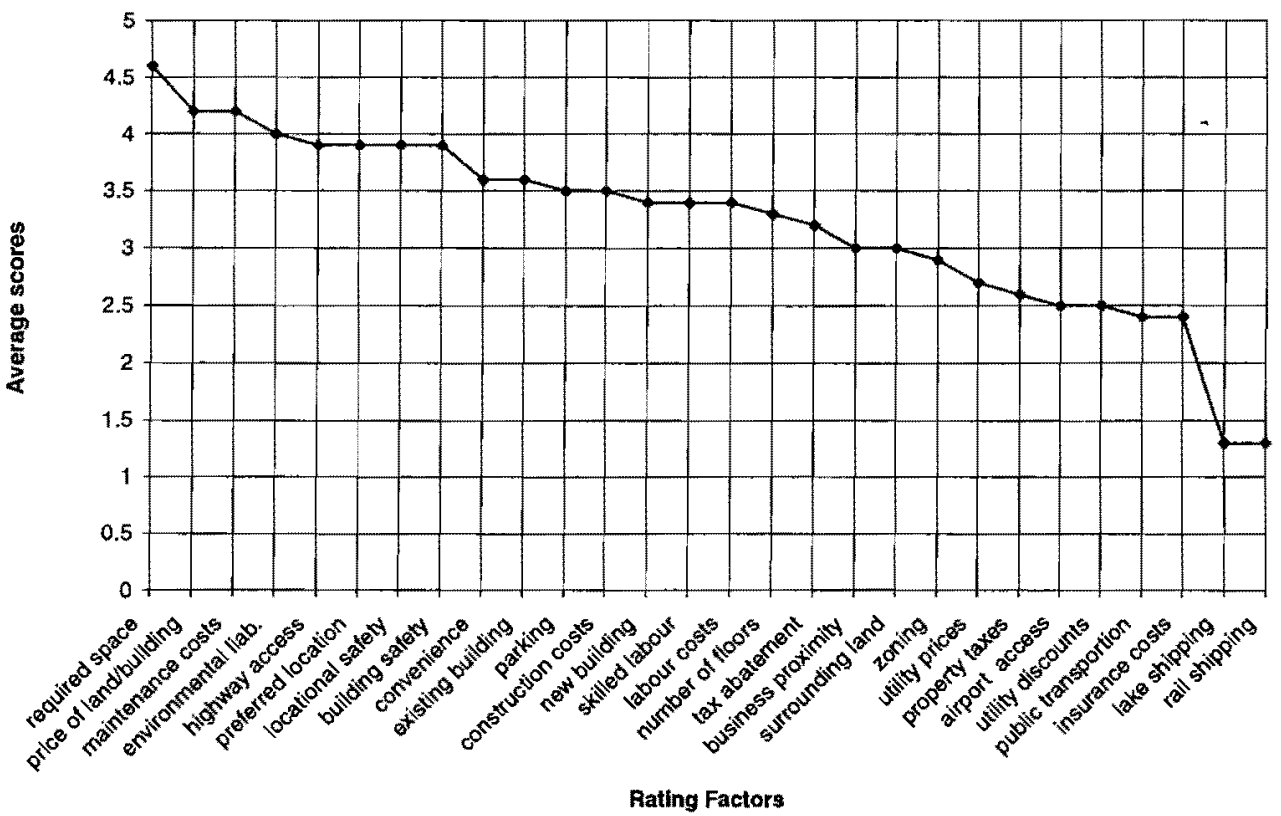

Price of land and building

Operating costs

Labour costs

Environmental liability

Factor 2: Amenities

Highway access

Parking

Labour skills

Factor 3: Location

Convenience

Desired location

\section{Environmental liability concerns}

When asked whether environmental liability issues arose in the selection process, one-third of the respondents answered 'yes'. Manufacturing firms were twice as likely to have encountered environmental liability issues as were firms in the service sector. On the other hand, just under half $(14 / 33)$ of the firms reported looking at a contaminated site, which was equally divided between manufacturing and service furms. About one-third of those who looked at a contaminated site reported that environmental liability issues had surfaced during the selection process. Approximately 50 per cent (17) of the respondents felt that environmental liability was an important factor in choosing a location. Of these 17 respondents, 14 rated environmental liability either at 4 or 5 on a frve-point rating scale (11 of the 17 rated environmental liability at 5 , with service firms twice as likely to have given this factor a 5 rating). It appears that, compared to service firms, manufacturing firms have a better understanding of environmental and brownfield issues and may be somewhat less intimidated by them.

While 82 per cent of the firms which encountered environmental issues were concerned about environmental liability, only about half of those firms (53 per cent) actually encountered potential brownfield issues in the search process. 


\section{Table 3: Factor analysis of 13 key variables (Canonical factor loadings)}

\begin{tabular}{|c|c|c|c|}
\hline & \multicolumn{3}{|l|}{ Factors } \\
\hline & 1 & 2 & 3 \\
\hline \multicolumn{4}{|l|}{ Variables } \\
\hline Highway access (Var 5) & 0.122 & 0.962 & -0.030 \\
\hline Parking (Var 7) & 0.480 & 0.585 & 0.191 \\
\hline Convenience (Var 11) & -0.213 & 0.127 & 0.834 \\
\hline Building size (Var 15) & 0.921 & 0.051 & -0.006 \\
\hline Existing building (Var 28) & 0.807 & -0.131 & -0.185 \\
\hline Desired location ( $\operatorname{Var} 34)$ & 0.038 & 0.007 & 0.871 \\
\hline Labour skills (Var 50) & -0.005 & -0.525 & -0.301 \\
\hline Locational safety (Var 60) & 0.878 & 0.198 & -0.093 \\
\hline Building safety (Var 61) & 0.946 & 0.208 & -0.010 \\
\hline Price land/building (Var 64) & 0.568 & -0.540 & 0.369 \\
\hline Labour costs (Var 65) & 0.371 & -0.259 & 0.344 \\
\hline Operating expense (Var 66) & 0.673 & -0.522 & 0.141 \\
\hline Environ. liability (Var 74) & 0.500 & 0.061 & 0.364 \\
\hline
\end{tabular}

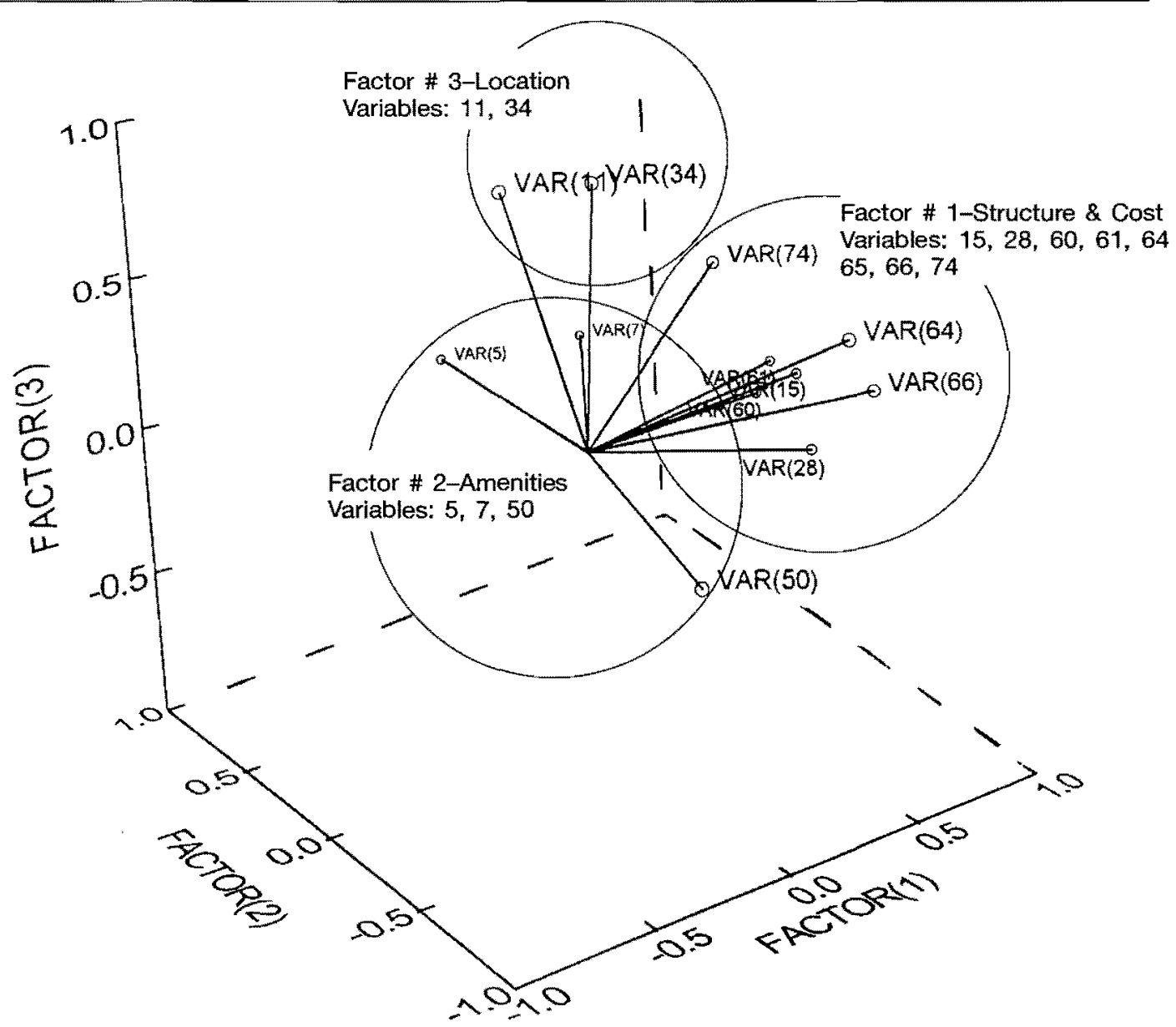

Figure 2 Factor loadings plot 
Thus, while a large majority of the firms appear to be concerned about potential liability once an environmental issue is identified, only half of the firms actually reported encountering such issues.

\section{Effect of environmental regulation on the location decision}

Eighteen firms indicated that they were subject to environmental regulation, divided equally between manufacturing and service firms. Being 'subject to regulation' is a rather broad categorisation, because the degree of regulation is not uniform and will probably vary by type of firm. For example, manufacturing and industrial firms are likely to be subject to more stringent and perhaps more complex regulations than service firms. Consequently, it may be more likely that they will have a resident environmental liability expert on the staff, which may reduce their concern in dealing with brownfield regulations compared to less experienced service firms. Perhaps for this reason, they seem to be less concerned regarding environmental issues than their less experienced service sector counterparts.

The survey respondents also answered questions regarding their familiarity with Ohio's VAP and the extent to which the VAP might influence their site-selection decisions. Thirteen firms, or approximately one-third of the sample, were aware of Ohio's VAP, which assists firms in the voluntary clean-up of contaminated sites. The law provides limited liability and some financial incentives for properties remediated under the programme. Only approximately one-third of the total sample was aware of the VAP. It is interesting to note, however, that 83 per cent of the firms aware of the VAP were subject to some form of environmental regulation, while only 50 per cent of the firms which were subject to environmental regulation were aware of the VAP. Clearly, there is room for greater awareness of the programme among those furms which could benefit most from it.

Surprisingly, whether or not firms are subject to environmental and brownfield regulation had little relationship to industry type, ie service or manufacturing. Furthermore, only three firms out of the 18 which were subject to environmental regulation indicated that the reduction in liability associated with the VAP would have influenced the furm's decision to clean up a contaminated site. Seen from another perspective, only three of the 12 firms that were aware of the VAP indicated that the reduction in liability it provides would have influenced their decision to relocate to a contaminated site to clean and develop it. It appears that while the VAP may be a step in the right direction, only a small percentage of furms find the programme sufficiently attractive to clean up and develop a contaminated site. Other factors need to be addressed, therefore, if the VAP is to be successful. Specifically, the non-environmental factors that influence corporate site-selection decisions must be addressed or incorporated into state and local efforts to encourage brownfield redevelopment.

In an effort to explore concerns regarding brownfield liability in more detail, a multivariate discriminant analysis was conducted using a quadratic classification function. The dependent variable was a firm's concern regarding potential environmental liability, while the following explanatory variables were included: industry type; importance of expense minimisation; whether the frrm encountered any environmental liability issues and/or viewed any contaminated sites; and whether the firm was subject to environmental and brownfield regulation. The canonical discriminant coefficients are: 
Table 4: Importance of final selection criteria

\begin{tabular}{|c|c|c|c|c|}
\hline \multirow[b]{2}{*}{ Factor } & \multicolumn{4}{|c|}{ Frequency of Top Three Ranks } \\
\hline & Rated 1 st & Rated 2nd & Rated 3rd & Total \\
\hline Site location & 6 & 8 & 5 & 19 \\
\hline Site size and configuration & 4 & 4 & 5 & 13 \\
\hline Transportation & 2 & 3 & 4 & 9 \\
\hline Taxes & 0 & 0 & 0 & 0 \\
\hline Cost of renovation/construction & 1 & 3 & 5 & 9 \\
\hline Skilled labour force & 3 & 1 & 4 & 8 \\
\hline Utilities/Insurance & 0 & 1 & 1 & 2 \\
\hline Crime/Safety & 1 & 2 & 0 & 3 \\
\hline Environmental liability & 0 & 0 & 0 & 0 \\
\hline Preference for new or existing bldg & 9 & 1 & 1 & 11 \\
\hline Other & 2 & 1 & 1 & 4 \\
\hline
\end{tabular}

- industry type - 0.450

- expense minimisation - 0.393

- brownfield issues - 0.727

- viewed contaminated sites -0.735

- subject to regulation - 0.070

The canonical scores of the group means are +0.888 for those firms which expressed a concern over environmental liability and -0.828 for those firms which did not. The results appear to be consistent and logical, because the positive coefficients on all the variables suggest that firms which are in the service industry are more expense conscious and have encountered environmental issues or visited contaminated sites, are subject to environmental regulation, and are more likely to have a concem regarding potential environmental liability. The size of the discriminant coefficient indicates the relative importance of each variable: hence, having encountered environmental or brownfield issues or having visited a contaminated site are the two most critical explanatory factors in the model. The model performed reasonably well, as it was able to classify between 66 and 83 per cent of the firms, depending upon the classification approach employed.

\section{Final decision criteria}

Respondents were asked to indicate the three most important factors in making their final site-selection decision. As indicated in Table 4, 19 out of 34 respondents rated site location as one of the top factors, with six respondents ranking location as the most important factor. Site size and configuration received 13 top-three ratings, with four firms indicating this as the single most important factor. Eleven respondents rated their preference for either a new or an existing building as one of the top factors, while nine indicated that this was the single most important factor. Transportation, cost of renovation or construction and availability of a skilled workforce received between eight and nine topthree ratings.

It is important to note that crime and safety and environmental liability, which were in the top group in terms of the initial screening criteria, failed to achieve a high score as final decision factors. 
Crime and safety received only three top-three ratings, while environmental liability received none. One possible interpretation of these results suggests that safety and environmental liability issues are so critical in the screening process that all unsafe or environmentally risky properties are screened out early in the decision-making process. Hence, the final short-list, of potential properties include only safe and environmentally clean properties, and as a result these two factors are not relevant in the final selection decision.

\section{CONCLUSIONS}

Statistical modelling of the data indicates that the respondents answered the survey in a consistent and logical manner. The data suggest that three broad factors influence relocation decisions: physical structure and cost; amenities; and location. Of the three, physical structure and cost is the dominant factor. The survey indicates that while environmental liability has a high priority in the early screening process, it does not appear to be an important factor in the final site-selection decision. Furthermore, firms which are more concerned about potential environmental liability are: more likely to be in the service industry; more expense conscious; and more likely to have encountered environmental or brownfield issues, have visited contaminated sites and be subject to environmental regulation.

From a site-selection strategy perspective, it appears that businesses tend to screen out environmentally impaired sites early in the site--selection process. Several non-environmental factors, such as land acquisition, building issues, and site size and configuration, are important both in the early screening process and in the final site-selection analysis. Reducing en- vironmental barriers to redevelopment is clearly critical, and the VAP attempts to encourage redevelopment by doing so. However, the VAP is apparently not exerting the desired influence, since many companies which knew about the programme indicated that it did not change their mind with respect to considering contaminated properties.

To become more effective at encouraging businesses to clean and redevelop brownfield properties, programmes like Ohio's VAP must either incorporate or work with other programmes that address the nonenvironmental factors that are critical to businesses' site-selection decisions. According to this survey, those factors include building size and status, safety of the location, land and building costs, operating costs, highway access, parking availability, local labour skills and convenience of the desired location.

In addition to making the benefits of the VAP better known to businesses, efforts to lure businesses to brownfields must address various non-environmental factors that are as important as environmental liability in the business decision-making process. Thus, efforts to encourage redevelopment must also address high-priority non-environmental factors, such as the required amount of building space, locational preference, site costs and configuration issues, preferences for new or existing structures and safety concerns. Although these factors may be difficult for many government agencies to control, understanding their importance may help cities focus their marketing efforts and develop more effective incentive programmes to stimulate brownfield development. Efforts should be made to identify businesses that can make effective use of sites which are consistent with the size and location of many brownfield properties. 


\section{REFERENCES}

(1) Gerrard, Michael B. (ed.) (1999) 'Brownfields Law and Practice: The Cleanup and Redevelopment of Contaminated Land' Lexis Publishing, New York; Eisen, Joel B. (1996) "Brownfields of Dreams": Challenges and Limits of Voluntary Cleanup Programs and Incentives', University of Illinois Law Review, p. 883 (discussing the purposes, strengths and shortcomings of numerous state voluntary clean-up programmes); Davis, Todd S. and Margolis, Kevin D. (eds) (1997) 'Brownfields: A Comprehensive Guide to Redeveloping Contaminated Properties', ABA, Chicago, Ill.; and United States Conference of Mayors (1996) 'Impact of brownfields on US Cities: A 39 City Survey".

(2) Ohio Revised Code, Chapter 3746. The implementing regulations for the VAP are at Ohio Admin. Code Chap. 3745-300.

(3) Roth, Stanton F. (1983) 'Current Trends in Corporate Relocation', Corporate Design, November-December, pp. 25-26.

(4) Goldstein, Mark L. (1985) 'Choosing the Right Site', Industry Week, 15th April, pp. 57-60.

(5) Bowlby, Ken (1988) 'The Corporate Location Decision: A Priority View of Multiple Criteria', Economic Development Review, Spring, pp. 37-39.

(6) Note, however, that Canadian law prohibits communities from providing incentives to the extent allowable in the United States: Bowlby, ref. 5 above, at p. 38.

(7) Tiller, Kay (1994) 'Corporate Site Selection: Incentive Importance Varies in Decisions, but Economics are Central to Moves', National Real Estate Investor, October, pp. 129-130.

(8) 'When You Want to Move Your Business: Tips on Choosing a New Location', Profit-building Strategies
(October 1990), pp. 6-7.

(9) Gooley, Toby N. (1998) 'The Geography of Logistics', Logistics and Distribution Report, January, pp. 63-65.

(10) Bergsman, Steve (1993) 'Incentives, Location, Quality of Life: All Figure into the Site Selection Equation', National Real Estate Investor, October, pp. 158-160; Klender, Mark (1993) 'Public Incentives', Business Facilities, August.

(11) Bergsman, ref. 10, p. 159; See also Krohe, Jr, James (1995) 'Relocation Reconsidered', Across the Board, February, pp. 41-46.

(12) Pollina, Ronald R. (1997) 'The Clients', Economic Development Review, Spring, pp. 70-74.

(13) Bergsman, ref. 10, pp. 158-160.

(14) Sheridan, Mike (1995) 'Site Selection Smorgasbord: Changing Work Patterns Force Choices', National Real Estate Investor, October, pp. 76-87.

(15) Emst \& Young and the International Association of Corporate Real Estate Executives (NACORE) (1994) 'Reshaping America: The Migration of Corporate Jobs and Facilities", Economic Development Review, Winter, pp. $85-89$.

(16) Mooney, James E. (1994) 'Creative Efforts at the Local Level for Providing Business Attraction and Expansion Incentives', Economic Development Review, Fall, pp. 52-57.

(17) Venable, Tim (1996) 'Economic Development's Rosy '97 Forecast: More Information, Better Service for Corporate Clients (Survey of Development Officials)', Site Selection, December, pp. 971-972.

(18) For more information regarding statutory and negotiated incentives as tools for development officials and benefits for companies, see Pollina, ref. 12 above.

(19) Block, Debbie Galante (1995) 'Lots of Expansion, Little Relocation', Plastics World, January, pp. 41-43. 